\title{
Nutritional Composition and Sensory Evaluation of Tapioca Fortified with Soy-Coconut Flour
}

\author{
Noah Abimbola . $\mathrm{A}^{1^{*}} \quad$ Abiaziem Chioma . $\mathrm{V}^{2}$ \\ 1.Department of Food Technology, The Federal Polytechnic Ilaro, P.M.B 50, Ogun State, Nigeria \\ 2.Science Laboratory Technology, The Federal Polytechnic Ilaro, P.M.B 50, Ogun State, Nigeria
}

\begin{abstract}
Tapioca is a cassava-based food product made in the form of irregular lumps of partly gelatinized starch grits. Tapioca was enriched with varying proportions of soy-coconut flour $(100,80: 10: 10,70: 15: 15,60: 20: 20$, 50:25:25) to produce tapioca soy-coconut. Proximate, mineral composition and sensory evaluation were determined by standard methods. The proximate composition of tapioca meals ranged in values of 7.67 to $10.67 \% ; 1.03$ to $30.09 \%, 0.24$ to $9.80 \%, 1.26$ to $4.71 \%, 1.08$ to $9.14 \%$ and 35.59 to $88.72 \%$ for moisture, crude protein, fat ,ash, crude fiber and carbohydrate respectively. There were increase in the values of tapioca as the level of soy-coconut flour substitution increased and significant differences $(p<0.05)$ in values obtained for moisture, protein, fat, ash and crude fibre contents. The mineral content of all the samples shows an increase in the value. Fortification of tapioca with soybean and coconut flour significantly increased the nutritional and sensory quality. The sensory evaluation result in terms of overall acceptability shows that 80:10:10 was most preferred than the other fortified samples. Hence fortified tapioca is recommended as safe, nutritious and acceptable food product that can enhance food and nutrition, security among cassava consuming population.
\end{abstract}

Keywords: soybean, cassava, tapioca, fortification, coconut

DOI: $10.7176 /$ FSQM/92-05

Publication date: December $31^{\text {st }} 2019$

\section{Introduction}

Cassava (Manihot esculentus) is a major staple food in the developing world, providing a basic diet for over half a billion people. It is one of the most drought tolerant crops, capable of growing on marginal soils. Nigeria is the world's largest producer of cassava, while Thailand is the largest exporter of dried cassava (Franquet et al., 2000). Cassava is classified as either sweet or bitter like other roots and tubers, both bitter and sweet varieties of cassava contain anti-nutritional factors and toxins with larger amounts. They must be properly prepared before consumption as enough residual cyanide to cause acute cyanide intoxication, goiters and even ataxia or partial paralysis (Adebowale et al., 2005). Cassava root is essentially a carbohydrate source, however, they are poor in protein and other nutrients (Olumude, 2004). A typical composition of the cassava root is moisture (70\%), starch (24\%), fibre (2\%), protein (1\%) and other substances including minerals (3\%) (Burell, 2003). Comparatively low content of vitamins and minerals. However the roots are rich in calcium and vitamin $\mathrm{C}$ and contain a nutritionally significant quality of thiamine. Cassava root can be cooked, eaten fresh or processed into flour (Montagnac et al., 2009). Cassava is processed into a variety of products such as 'gari', 'fufu', 'elubo', 'abacha' and tapioca in Nigeria and some parts of the tropics (Balogun et al, 2012). Tapioca pearls are small white spheres, each about $2 \mathrm{~mm}$ in diameter. Tapioca is essentially a flavorless starchy ingredient produced from treated and dried cassava root (FAO, 2005). It is a staple food commonly consumed with cow milk because of it low nutritive value and blande taste (Adeniyi et al., 2017). Soybean (Glycine max) is a species of legume native to East Asia. Soy bean meal is a significant and cheap source of protein for animal feeds and many packaged meals (Riaz, 2006).

The beans contain significant amounts of phytic acid, dietary minerals and B vitamins. Soy beans is an excellent source of nutrient It contains $40 \%$ protein, $20 \%$ oil, $35 \%$ carbohydrate, $3 \%$ ash and moisture content about 10-13\% (Liu,1997, Purcel et al., 2000).

The term Coconut (Cocos nucifera) can be referred to the whole coconut palm or the seed, or the fruit, which botanically, is a drupe, not a nut, (Daigado, 2001, Rosengarten, 2004)). The various parts of the coconut have a number of culinary uses. The seed provides oil or for frying, cooking and making margarine, the white, fleshy part of the seeds, the coconut meat is used fresh or dried in cooking, especially in confections and desserts such as macaroons. Coconut flour is a soft flour like product made from the pulp of a coconut. It's actually a by-product made during the coconut milk making process. Coconut flour is extremely high in fiber with almost double the amount found in wheat bran (Lalitha, 2014). Coconut flour has also been developed for use in baking, to combat malnutrition (Trinidad et al., 2001). According to Arancon (1999), nutrient composition of coconut flour is mentioned as; protein $13.41 \%$, moisture $2.80 \%$, crude fat $10.23 \%$ and crude fibre $19.3 \%$. Trinidad et.al, (2006) reported that the dietary fibre content of coconut flour was $60.0+/-1.0 \mathrm{~g} / 100 \mathrm{~g}$ sample, $56 \%$ insoluble and $4 \%$ soluble. Tapioca pearls contain $8.79 \%$ of moisture $0.55 \%$ of protein, $0.345 \%$ fat, $0.32 \%$ ash, $0.10 \%$ crude fibre and $89.62 \%$ carbohydrate (Ojo et al., 2017). Due to the poor nutritive value of Tapioca, hence fortifying 
Tapioca pearls with soybeans and coconut flour may be a relatively cheaper way of enriching it nutrient. The objective of the study is to evaluate the nutritional and sensory properties of Tapioca pearls fortified with different proportion of soybean and coconut flour.

\section{Materials and Method}

2.1 Materials

Source of materials: The freshly harvested cassava tuber, coconut and soybean used for this study were obtained from Sayedero market Ilaro Ogun State.

\subsection{Preparation of Samples}

\subsubsection{Production of soy bean flour}

Soy bean seeds were cleaned to remove all dirt, bad seeds and foreign materials. The soybeans seeds were soaked in water for about 18 hours to soften the hulls before dehulling. The soybean seeds were then dehulled and cooked for 20 minutes to remove antitrypsin inhibitors. The cooked soybean was then dried in a cabinet dryer. The dried and dehulled soybeans seeds were then milled into flour.

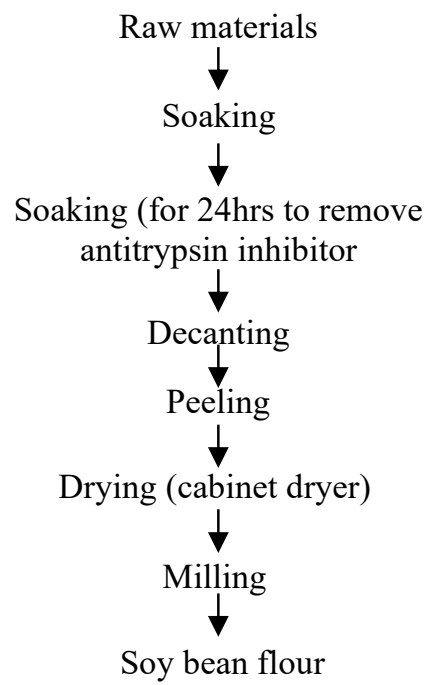

\subsubsection{Production of coconut flour}

Figure 1. Flowchart of soy bean flour

Coconut were washed to remove all dirty and the coconut was them break to remove the shell. After removing the shell it was peeled to remove the brown cover at the back of the coconut and the coconut was grated with a grater. After grating it was soaked in hot water to reduce the oil content in the coconut after decanting after which it was dried with a cabinet dryer. After drying coconut were then milled into flour with a hammer mill. 


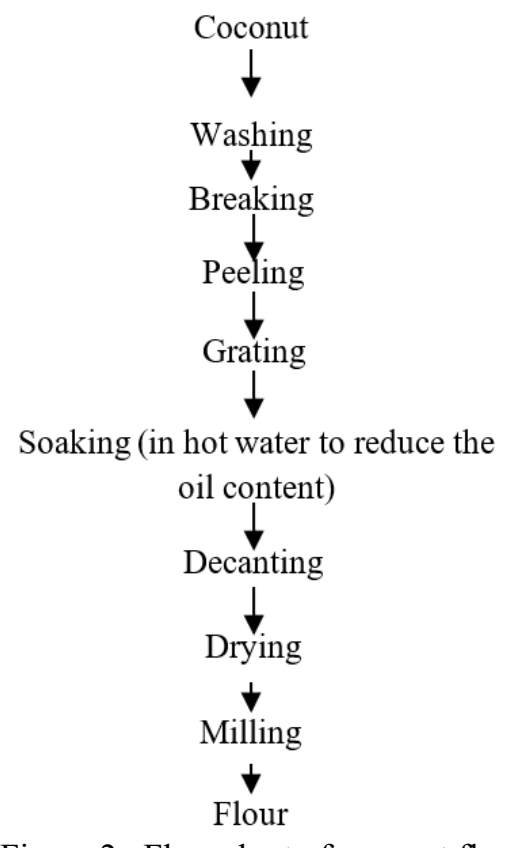

Figure 2. Flow chart of coconut flour

\subsubsection{Production of tapioca grits}

Cassava starch was produced using traditional methods as described by Asiedu (1989). 100kg fresh harvested cassava root was peeled washed and grated with a diesel engine powered mechanical grater. The resultant pulp was immediately sieved through screen and suspended in $60 \%$ of water. This separates the fibrous and coarse root material from the starch pulp. The starch pulp was left for 4 hours before decanting. The thick starch cake at the bottom of the bowl was pressed to remove water. This was screened through a mesh to produce a coarse grain moist starch fibrous The resulting starch was oven dried at $40^{\circ} \mathrm{c}$ for $30 \mathrm{mins}$ ( see Fig 3 ).

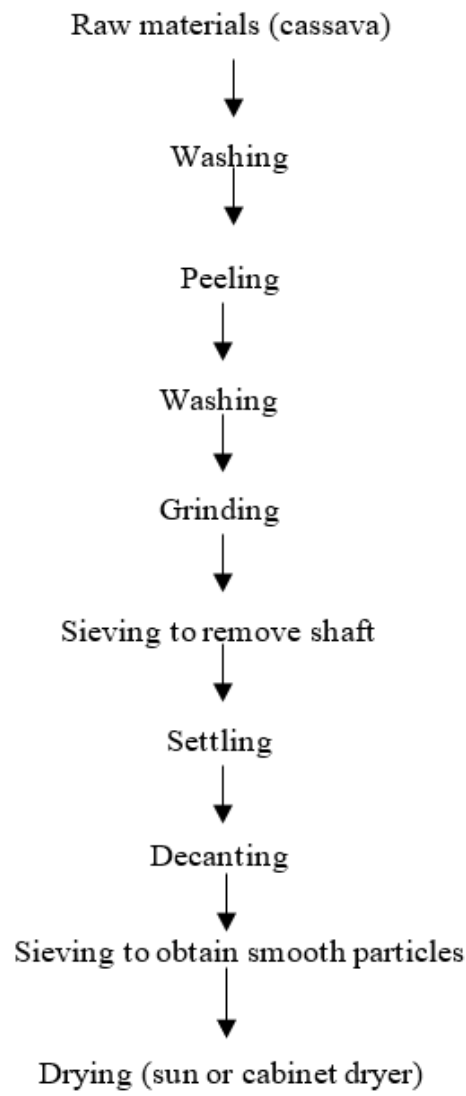

Figure 3. Flow chart on production of tapioca (cassava starch) 


\subsubsection{Formulation of enrich tapioca meal}

Production of soy-coconut tapioca was produced by the incorporation of Cassava, soybeans and coconut flour in ratio 100;0, 80;10:10, 70:15:15, 60:20:20 and 50:25:25 respectively. The mixture was moistened with water in the ratio $2: 1$ of water to flour roasted into the damp just before roasting in the pan.

\subsubsection{Proximate analysis}

The proximate analysis( Moisture, content, crude fibre protein, ash, fat was determine by AOAC ,(2000). Carbohydrates was calculated by differences.

\subsection{Sensory evaluation}

Sample of tapioca fortified with soy-coconut flour were subjected to sensory evaluation by nine (9-panelists familiar with tapioca, while they were also instructed on the use of sensory evaluation procedures. Each of the panelist were asked to rate the samples on the basis of flavour, taste colour, appearance and overall acceptability using a nine point hedonic scale.

\subsection{Statistical Analysis}

All determinations were carried out in triplicates. In each case, a mean value and standard deviation was calculated. Analysis of variance (ANOVA) was also performed and separation of mean value was by Duncan's multiple Range Test at $(\mathrm{P}<0.05$.). Correlation coefficients were also calculated using statistical package for social science scientists (SPSS) software version 10.

\subsection{Results and Discussion}

The result of the proximate composition of Tapioca fortified with Soybean and coconut flour is presented in Table 1.

Table 1. Proximate composition of tapioca fortified with soybean and coconut flour

\begin{tabular}{lllllll}
\hline Sample & Moisture & Protein & Fat & Ash & Crude fibre & Carbohydrate \\
A & $7.67^{\mathrm{c}} \pm 0.03$ & $1.03^{\mathrm{a}} \pm 0.01$ & $0.24^{\mathrm{b}} \pm 0.02$ & $1.26^{\mathrm{c}} \pm 0.04$ & $1.08^{\mathrm{c}} \pm 0.05$ & $88.72^{\mathrm{a}} \pm 0.21$ \\
B & $8.40^{\mathrm{a}} \pm 0.12$ & $12.65^{\mathrm{a}} \pm 0.23$ & $4.07^{\mathrm{a}} \pm 0.12$ & $2.62^{\mathrm{b} \pm 0.21}$ & $4.26^{\mathrm{c}} \pm 0.12$ & $65.98^{\mathrm{b}} \pm 0.04$ \\
C & $8.57^{\mathrm{a}} \pm 0.03$ & $18.74^{\mathrm{c}} \pm 0.19$ & $5.98^{\mathrm{b}} \pm 0.01$ & $3.33^{\mathrm{b} \pm 0.06}$ & $5.91^{\mathrm{a}} \pm 0.01$ & $57.47^{\mathrm{a}} \pm 0.08$ \\
D & $8.86^{\mathrm{a}} \pm 0.11$ & $23.46^{\mathrm{b}} \pm 0.15$ & $7.89^{\mathrm{b}} \pm 0.03$ & $4.02^{\mathrm{b}} \pm 0.07$ & $7.52^{\mathrm{b} \pm 0.04}$ & $48.25^{\mathrm{b}} \pm 0.07$ \\
E & $10.67^{\mathrm{b}} \pm 0.21$ & $30.09^{\mathrm{b}} \pm 0.11$ & $9.80^{\mathrm{c}} \pm 0.05$ & $4.71^{\mathrm{c}} \pm 0.05$ & $9.14^{\mathrm{c}} \pm 0.23$ & $35.59^{\mathrm{c}} \pm 0.11$ \\
\hline
\end{tabular}

Values represent mean and standard deviation means with the same superscript are within the column are significantly different $(\mathrm{P}<0.05)$

Key: Sample A $=100 \%$ Cassava starch, Sample B=80\% Cassava starch 10\% Soybean flour: 10\% Coconut flour, Sample $C=70 \%$ Cassava starch 15\%Soy bean flour: 15\% Coconut flour, Sample D=60\% flour: 20\% Soy beans flour: $20 \%$ Coconut flour, Sample E =50\% Cassava starch: $25 \%$ Soy bean flour: $25 \%$ Coconut flour.

\subsection{The Proximate Composition}

The proximate composition of Tapioca fortified with soy-coconut flour was presented below in Table 1 . Moisture content ranged from $7.67 \%$ to $10.67 \%$ respectively. Ample E has the highest moisture content of $10.67 \%$ compared to sample $\mathrm{C}$ with $8.57 \%$ and the least moisture content was observed in sample A which is $7.67 \%$. The values of the moisture content were significant different from each other as the increase in the level of addition of soy -coconut flour.

The protein content increases with increase in the substitution of soy-coconut flour. This observation agrees with previous findings of (Iwe, 2003 and Balogun et al., 2012). The protein content range from 1.03\% to $30.09 \%$ respectively. Among the tapioca produced, the control sample which is sample A has the lowest protein content of $1.03 \%$ while sample $\mathrm{E}$ has the highest protein content $(30.09 \%)$.

The fat content of the tapioca soy-coconut flour ranged from $0.24 \%$ to $9.80 \%$ respectively. Low fat content makes it suitable as a refreshing and a thirst quenching product which is a characteristic of a good beverage reported by Agarry et al. (2010). The Ash content of tapioca fortified with soy-coconut flour ranged from $1.26 \%$ to $4.71 \%$.This follow similar trend observed in protein and fat content .This has shown that added soy and coconut flour increase the ash content. Samples A has low ash content $1.08 \%$ and sample E has the highest ash content of $9.14 \%$. The crude fibre content ranges from $1.08 \%$ to $9.14 \%$ respectively and significant difference exist within the values The fibre increases with an increase in the substitution of the soy-coconut flour. The increase was due to the high fibre in coconut flour.

The carbohydrate content of the tapioca ranged from $35.59 \%$ to $88.72 \%$ respectively. The control sample which is A had the highest value (88.72\%) while sample E had the lowest carbohydrate content of $35.39 \%$. This shows that carbohydrate content decreases with an increase in soy-coconut substitution. This observation agrees with the work of (Obadina et al., 2010) 
Table 2: Mineral Composition of Tapioca Enriched with Soy - Coconut Flour

\begin{tabular}{lllll}
\hline Sample & Sodium $(\mathrm{mg} / 100 \mathrm{~g})$ & Potassium $(\mathrm{mg} / 100 \mathrm{~g})$ & Calcium $(\mathrm{mg} / 100 \mathrm{~g})$ & Phosphorous mg/100g \\
A & $4.50^{\mathrm{a}} \pm 0.01$ & $23.35^{\mathrm{a}} \pm 0.01$ & $8.90^{\mathrm{a}} \pm 0.01$ & $33.35^{\mathrm{a}} \pm 0.01$ \\
B & $7.3^{\mathrm{a}} \pm 0.01$ & $27.11^{\mathrm{b}} \pm 0.01$ & $15.14^{\mathrm{a}} \pm 0.01$ & $35.01^{\mathrm{a}} \pm 0.01$ \\
C & $9.41^{\mathrm{b}} \pm 0.01$ & $29.32^{\mathrm{a}} \pm 0.01$ & $16.75^{\mathrm{b}} \pm 0.01$ & $37.23^{\mathrm{b}} \pm 0.01$ \\
D & $11.03^{\mathrm{c}} \pm 0.01$ & $31.00^{\mathrm{a}} \pm 0.01$ & $19.60^{\mathrm{b}} \pm 0.01$ & $39.09^{\mathrm{b}} \pm 0.01$ \\
E & $15.20^{\mathrm{a}} \pm 0.01$ & $34.74^{\mathrm{a}} \pm 0.01$ & $21.07^{\mathrm{b}} \pm 0.01$ & $42.80^{\mathrm{a}} \pm 0.01$ \\
\hline
\end{tabular}

\subsection{Mineral Composition}

The results of mineral analysis of the samples are shown in Table 2 above. The values estimated for all minerals showed significant difference $(\mathrm{P}<0.05)$ between samples and increase with increase in the fortification of soy coconut flour. The mean percentage for sodium ranged from 4.5 to $15.20 \mathrm{mg} / 100 \mathrm{~g}$. Potassium ranged from 23.35 to $34.74 \mathrm{mg} / 100 \mathrm{~g}$, calcium ranged from $8-90$ to $21.07 \mathrm{mg} / 100 \mathrm{~g}$ and phosphorus ranged from 33.35 to 42.80 $\mathrm{mg} / 100 \mathrm{~g}$. The fortified samples are better source of minerals compared to unfortified sample. The high level of calcium in fortified samples would promote good bone and tooth health for adults and children. Phosphorus in fortified samples is important in preventing bone loss, decreased growth and poor tooth development, while sodium and potassium is important in the regulation of body fluids.

\subsection{Sensory Evaluation}

Table 3. Sensory scores of tapioca enriched with soy - s coconut flour

\begin{tabular}{cclllll}
\hline Sample & Appearance & Color & Aroma & Texture & Taste & Acceptability \\
A & $4.20 \pm 0.13^{\mathrm{a}}$ & $8.27 \pm 0.07^{\mathrm{a}}$ & $4.07 \pm 0.05^{\mathrm{a}}$ & $8.00 \pm 0.00^{\mathrm{a}}$ & $8.67 \pm 0.01^{\mathrm{a}}$ & $4.27 \pm 0.07^{\mathrm{a}}$ \\
$\mathrm{B}$ & $4.00 \pm 0.01^{\mathrm{b}}$ & $7.67 \pm 0.013^{\mathrm{b}}$ & $3.73 \pm 0.11^{\mathrm{b}}$ & $7.80 \pm 0.13^{\mathrm{b}}$ & $8.33 \pm 0.07^{\mathrm{b}}$ & $3.90 \pm 0.011^{\mathrm{b}}$ \\
$\mathrm{C}$ & $3.67 \pm 0.01^{\mathrm{c}}$ & $6.87 \pm 0.013^{\mathrm{bc}}$ & $3.57 \pm 0.01^{\mathrm{bc}}$ & $7.40 \pm 0.02^{\mathrm{c}}$ & $7.13 \pm 0.00^{\mathrm{ab}}$ & $3.60 \pm 0.05^{\mathrm{c}}$ \\
$\mathrm{D}$ & $3.70 \pm 0.11^{\mathrm{b}}$ & $7.20 \pm 0.01^{\mathrm{c}}$ & $3.67 \pm 0.07^{\mathrm{c}}$ & $7.00 \pm 0.01^{\mathrm{bc}}$ & $7.00 \pm 0.05^{\mathrm{bc}}$ & $3.77 \pm 0.013^{\mathrm{b}}$ \\
$\mathrm{E}$ & $3.67 \pm 0.05^{\mathrm{c}}$ & $7.13 \pm 0.02^{\mathrm{ab}}$ & $3.70 \pm 0.013^{\mathrm{b}}$ & $7.13 \pm 0.03^{\mathrm{ab}}$ & $7.67 \pm 0.11^{\mathrm{c}}$ & $3.88 \pm 0.02^{\mathrm{b}}$ \\
\hline
\end{tabular}

Values represent mean and standard deviation means with the same superscript within the column are significantly different $\left(\mathrm{P}_{\leq} 0.05\right)$

These results show that all samples were found to be acceptable because their scores were above average. Sample B with $80 \%$ cassava starch and $10 \%$ soy and $10 \%$ coconut flour was rated highest among the fortified samples in terms of colour (7.67), texture (7.80) and taste (8.33). The sample with $100 \%$ cassava starch was rated highest in terms of overall acceptability because they commented that $80 \%$ cassava starch with $10 \%$ soy coconut flour was not as white as that from cassava starch alone $(100 \%)$ which may be due to the characteristics of yellow pigment in the soy bean flour and browning reaction from coconut during processing. Sample B was also rated high in terms of overall acceptability among the fortified samples though slight significant differences exist among the samples. Thus, this result shows that up to $25 \%$ substitution is possible to enriched cassava starch with acceptable qualities.

\subsection{Conclusion}

Incorporation of soy coconut flour into the tapioca with varying ratio has effects on the nutritional and sensory properties of the product. Soy coconut fortification resulted in improvement of protein, carbohydrates, fiber and mineral contents. However, fortification of tapioca with soy coconut flour with sample B had the highest overall acceptability among the fortified samples. Hence the addition of soy coconut flour to cassava starch was recommended up to $25 \%$ level. It can also provide a nutrient dense alternative to tapioca and enhance household food and nutritional security.

\section{Acknowledgement}

The Authors wish to appreciate the effort of Olojede Fowomola Tolani for assisting in the laboratory research work.

\section{References}

Adebowale, A.A., Sanni, L.O. and Awonorin, S.O. (2005). Effect of texture modifiers on the physicochemical and sensory properties of dried fufu. Food Sci Techn.11(5):373-382.

Adeniyi P. O., Obatolu Veronica A., Bakare A.D., Lawal S.B., Bolaji A.T., Banjo O.A. (2017). Fortification of Carbohydrate-rich Foods (Spaghetti and Tapioca Pearls) with Soybean Flour, a Timely and Evergreen Necessity .Journal of Food Security. 2017, 5(2), 43-50.

Association of Official Analytical Chemists (AOAC, 2000). Official Methods of Analysis (17 ${ }^{\text {th }}$ Edition). Washington D.C. 
Asiedu, J.J. (1989). Processing Tropical Crops: A technological Approach. (1st ed.) 3-8. London: Macmillan Publishers.

Balogun M.A., Karim O.R., Kolawole, F.L. and Solarin A.O. (2012). Quality Attributes of Tapioca Meal Fortified With Defatted Soy Flour. Agrosearch 12. No. 1: $61-67$.

Burell, M. M. (2003). 'Starch: The Need for Improved Quality or Quantity: An Overview.' Journal of Experimental Botany 54 (382): 451- 456.

Dalgada, Sebastiao. "Glossario Lusoa slatico." Google.com. p.291

Franquet Claude and Denis Faigete (1990) "African cassava mosaic virus: etiology, epidemiology and control" plantdisease vol. 74(6): 404-11.(1) Csu safe food newsletter, summer 2005-vol9 No. 4-Botulinum toxin: friend ca to America or foe .

Food and Agricultural Organization (FAO, 2005). Food Outlook. 36

Lalitha Ramaswamy ( 2014 ) Coconut Flour - A Low Carbohydrate, Gluten Free Flour A Review Article : International journal of ayurvedic \& herbal medicine 4(1) 2013(1426-1436)

Liu R. (1997). Soybean: Chemistry, Technology and Utilization. Springer. U.S.A.

Montagnac J.A, Davis C.R, Tanumihardjo SA. 2009. Processing techniques to reduce toxicity and antinutrients of cassava for use as a staple food. Comp Rev Food Sci Food Safety 8: 17- 27.

Obadina, A.O., Oyewole, O.B. and Olaleye, A.O. (2010). 'Development and Evaluation of Fortified Tapioca Meal with Coconut and Banana Pulp'. Nigerian Food Journal. 28 (2): 294-301.

Olumide O. Tewe (2004) "The global cassava development strategy"

Purcel, Larry C; Salmeron, mont serrat; Ashlock Lanny (2014) “Chapter 2" soybean production handbookMP197.

Riaz,miam. N (2006). Soy Applications in Food Boca Ration, FL CRC press. ISBN 0-8493 - 298, 1-7.

Rosengarten, Frederic Jr. (2004). The Book of Edible Nuts. Dover Publications. pp. 65-93 Archived April 21, 2016, at the Wayback Machine. ISBN 978-0-486-43499-5

Trinidad, P.T., Divinagracia,H.V.,Aida,C.M.,Faaridah,C.A.,Angelica,S.M.,Modesto,T.C.,Askali, C.A., Loyola, A.S., and Masa, D.B., (2001). "Coconut flour from residue: A good source of dietary fibre", Indian Coconut Journal, $X X X I I(6)$, pg.9-13.

Trinidad, P.T., Mallillin, A.C., Valdez, D.H., Loyola, A.S., Castillo,J.C., Encabo, R.R., Masa, D.B., Maglaya, A.S. and Chua, M.T., (2006) " Dietary fiber from coconut flour", A functional food Innovative Food Science and Emerging Technologies, 7: 309-317. 